\title{
Influence of Technological Factors on Organizational Performance of Airlines: A Case Study Kenya Airways Ltd
}

\author{
Esther N. Mwangi \& Dr Sussy Wekesa \\ Department of Entrepreneurship, Technology, Leadership \& Management, Jomo Kenyatta University of \\ Agriculture \& Technology P.O. BOX 62000-00200 Nairobi, Kenya, Esther N. Mwangi P.O. Box 52790-00200 \\ Nairobi.
}

\begin{abstract}
The aviation sector is probably the most important mode of transport intermediary in the economy because of the role it plays as the quickest mode of transport for both passengers and freight. Air travel remains a large and growing industry. It facilitates economic growth, world trade, international investment and tourism and is therefore central to the globalization taking place in many other industries. A country such as Kenya which relies heavily on foreign earnings through the export of agricultural produce is a direct beneficiary of airline services. Statistics indicate that Kenya Airways posted kes 25.7bn loss in the 2014/2015 financial year and this was largely attributed to change in the macro-environmental forces. The effect of macro-environmental forces on the organizational performance of the airline industry especially in Kenya has received little attention in academic research. This study sought to establish the influence of technological factors on organizational performance of Kenya Airways. This study adopted descriptive research design and was limited to two financial years, 2013/2014 and 2014/2015, due to resource constraints. The target population of this study was 245 staff working in Kenya Airways Finance department. Stratified random sampling was used to select 74 respondents. The researcher used a questionnaire as primary data collection instrument. Secondary data was collected from published materials and annual reports of Kenya Airways. Content analysis and descriptive analysis was employed. In addition, a multiple regression was used. The study established that technological factors influence the organizational performance of Kenya Airways Limited. The study also recommends that there is need for the management of Kenya Airways to adopt modern technologies in the airline industry. This will help in making them competitive and thus improving its performance.
\end{abstract}

Keywords: Technological factors, Organizational performance

\section{INTRODUCTION}

The organizations' environment is the set of forces surrounding an organization that have the potential to affect the way it operates and its access to scarce resources. The organization needs to properly understand the environment for effective management (Davis \& Powell, 2012). Thus, environment is the influences that an organization must manage and is composed of the institutions or forces outside the organization that potentially affect the organization's performance (Rao, 2008). The external environment consists of the political, economic, social, technological, environmental and legislative, as well as industry forces. Johnson and Scholes (2007) argue that studying these forces is critical and enables a firm evaluate its competitive position vis a vis its strategy, internal resource capabilities and stakeholder acceptability. The environment not only moderates the relationship between decision-level factors highlighted in previous studies (Hough \& White, 2003) but it also impacts the consistency of the direction themselves (Mitchell et al., 2011). Further, the environment determines the structure of an organization and the two basic factors that define an organization environment are complexity and stability (Hough \& White, 2003). Organizational performance is a measure of the change of the state of an organization, or the outcomes that results from management decisions and the execution of those decisions by members of the organization (Robert et al., 2006. Performance can be defined as an approach to determining the extent to which set objectives or goals of an organization are achieved in a particular period of time (Illo, 2012). The objectives or goals can be in financial or non-financial terms; therefore, performance can also be financial or non-financial. This is one measure of organizations overall performance, and from stakeholders strategic purpose, it is the purpose of the firm (Friendman, 2010).

\section{STATEMENT OF THE PROBLEM}

The external environment in which a firm operates presents the firm with opportunities, threats and constraints. It consists of macroeconomic factors which include political, economic, social, technological, environmental, and legal factors. These have a huge impact on organizational performance of the airline industry and thus, airlines cannot afford to ignore them as they will determine whether or not they sustain 
competitive advantage. The airline businesses depends on the wellbeing of international trade and the stability of the environment in which they operate. Before creating business plans or when evaluating existing ones it is important to therefore 'scan' the external environment. Statistics indicate that Kenya Airways posted kes $25.7 \mathrm{bn}$ loss in the 2014/2015 financial year and this was partly attributed to these technological factors as the existing fleet had high maintenance and fuel costs. In a bid to respond to the environmental forces, Kenya Airways upgraded its aeroplanes by ordering its first Boeing 787 Dreamliner (KQ Annual Report, 2014).The effect of technological factors on the organizational performance of the airline industry especially in Kenya has received little attention in academic inquiry. Studies done on Kenya Airways have not tackled the issue of the technological factors and their influence on the company's organizational performance (Rajula, 2012; Irungi, 2012; Rono, 2012; Muhia, 2012; Mutia,2011; Kimeu, 2011; Kubai, 2010; Waime, 2010; Gwako, 2008; Gichira, 2007; Ochieng, 2006; Makori, 2006; Chamayiek, 2005). It is in this light that the study seeks to fill the existing research gap by carrying out a study to establish the influence of technological factors on organizational performance of airlines, with special focus on Kenya Airways.

\section{Research objectives}

The main objective of this study was to establish the influence of technological factors on organizational performance of Kenya Airways Limited.

\section{LITERATURE REVIEW}

This study was guided by two theories namely Open Systems Theory and Contingency theories. Open systems theory was developed after World War II in reaction to earlier theories of organizations, some of which included human relations perspective of Elton Mayo and the administrative theories of Henri Fayol, which treated the organization largely as a self-contained entity. Organizations are environment-serving, such that they cannot completely control their own behavior and are influenced in part by external forces (Ansoff \& McDonnell, 2010). According to Lynch (2003) an organization can use its corporate strategy to link processes between management of organization's internal resources and its external relationship with its customers, suppliers, competitors and the economic and social environment in which it exists. The organization influences and is influenced by the environment in which it operates. Contingency theories are a class of behavioral theories that basically reject "the one best way" approach to management and organizational structure. Fiedler, (1964) stated that the structural and management styles adopted are dependent (contingent) on the situational (contextual) variables facing the organization. The contingency theories relate to how the organizational structure adjusts to fit with both the internal environment such as work technology and the external environment such as economic or political/legal. Contingency means that one thing depends upon another thing or that one characteristic depends upon another characteristic (Ansoff \& McDonnell, 2010).

\subsection{Conceptual Framework}

\begin{tabular}{|c|c|}
\hline $\begin{array}{l}\text { Technological Factors } \\
\text { - } \quad \text { Fleet Development } \\
\text { - } \quad \text { E-Commerce }\end{array}$ & $\begin{array}{l}\text { Organizational Performance } \\
\text { - Efficiency } \\
\text { - Growth }\end{array}$ \\
\hline
\end{tabular}

Independent Variable

\section{Dependent Variable}

Figure 1: Conceptual Framework

The independent variable in this study is technological factors while the dependent variable is organizational performance. The increased use of computer programs, technological trends and innovations, increasing speeds in producing units, smart systems, improvements in artificial intelligence and diversification are examples of technological forces (O'Connor, 2000). Technological advancement has been the driving factor for improving airlines' operational efficiency. Airlines have been able to reduce costs and improve operations by using advanced aircraft engine technology, IT solutions, and mobile technology. Technology has created better connectivity and enhanced passengers' travel experience. Technological factors that will be studied are fleet development and e-commerce. Kenya Airways recent fleet renewal program will mean reduced fuel consumption which directly improves the airlines performance. The new aircrafts have revolutionarised the aviation industry and KQ's acquisition would dovetail into achievement of Vision 2030. Under the blueprint for national development covering the period 2008 to 2030, Kenya intends to 
become one of the world's top 10 long-haul destinations. E-commerce as sales channel has shown major improvements as result of various initiatives that have been put in place to drive online sales e.g PayPal (www.kenya-airways.com). Kenya Airways has also partnered with Safaricom Ltd to enable its passengers to redeem bonga points for air tickets. Mpesa services offered by Safaricom Ltd has enhanced the mode of payments available and has enabled passengers to book and pay for their air fare at the comfort of their homes. Organizational performance in this study is measured in terms of efficiency and growth. Return on Equity (ROE) is one of the ways used to measure efficiency. It indicates how effectively the management of the enterprise is able to turn shareholders' funds into net profit. Growth has long been considered a critical and distinct component of organizational performance (Hassan \& Bashir, 2003). Change in revenue was used as a growth measure in this study. Change in revenue can be an indication of a company's health and future prospects and is therefore an important step for investors when analyzing a business or stock.

\section{RESEARCH METHODOLOGY}

A research design is the framework for a study that is used as a guide in collecting and analysing data (Kottler \& Armstrong, 2000). Descriptive research design is used in cases where the researcher expected to have the target group explain or describe certain issues about important variables of the study. According to Mugenda and Mugenda (2008) it is important and appropriate to use data where subjects are observed in either natural set ups without manipulating the environment. It can be used when collecting information about people's attitudes and opinions. It is an efficient way to obtain information needed to describe the attitudes, opinions and views of Kenya Airways staff on the influence of technological factors on organizational performance of airlines. This research adopted a descriptive research design where the population of interest who were visited were the employees who work in the Finance Department. The design is deemed appropriate because the main interest was to explore the viable relationship and describe how the factors support matters under investigation. Descriptive design provided quantitative data from cross section of the chosen population.

\section{Research Findings}

The data was then analyzed using descriptive and inferential statistical measures as follows:

\subsection{Demographic Characteristics of Respondents}

The demographic characteristics that were used include age and gender of the respondents, their highest level of education and their level in the organization.

From the findings, the study found that most of the respondents as shown by $44.3 \%$ indicated 30 to 39 years, $24.3 \%$ indicated 40 to 49 years, $21.4 \%$ indicated 20 to 29 years and $10.0 \%$ indicated 50 and above years. This is an indication that most of the respondents were well distributed in terms of their age.

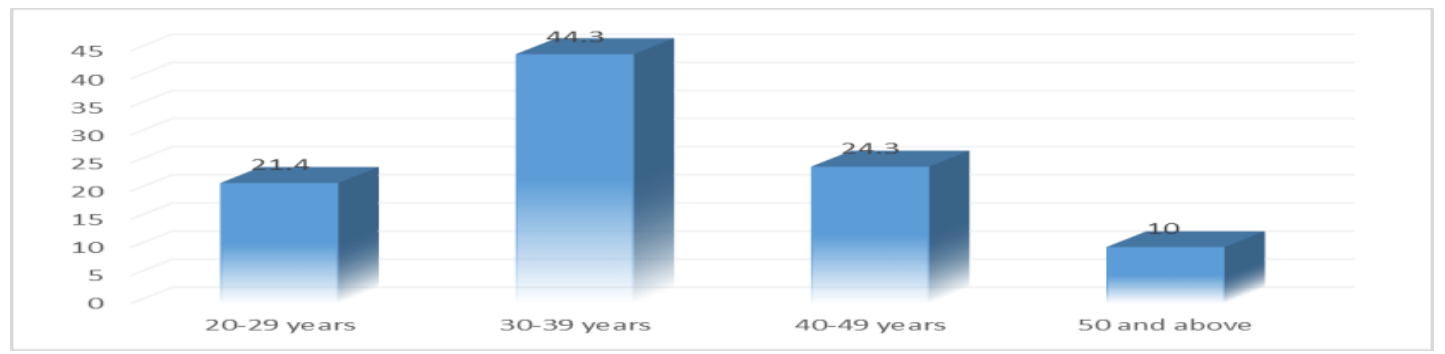

Figure 2: Age of Respondents

The study found that majority of the respondents as shown by $55.7 \%$ was female while $44.3 \%$ were male. This is an indication that both male and female were involved in this study through not in equal proportion and therefore the findings of the study could not suffer from gender biasness.

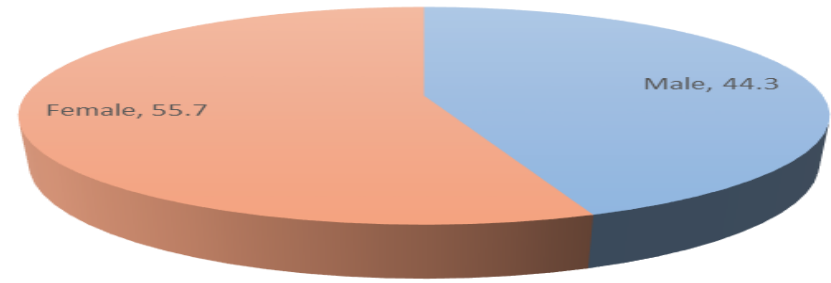

Figure 3: Gender of Respondents 
From the findings, the study found that most of the respondents as shown by $40 \%$ had degree, $38.5 \%$ had masters and $21.5 \%$ had qualifications in other professional courses. This is an indication that most of the respondents were learned and they were in a position to understand the questions and give credible information relating to the study.

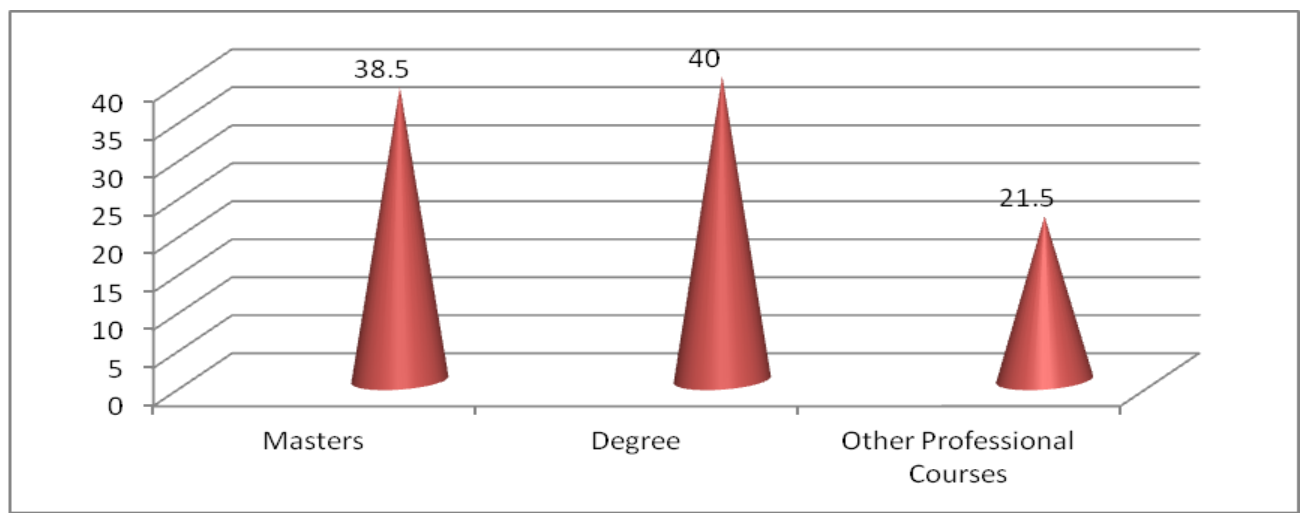

Figure 4: Highest Level of Education of Respondents

The study found that majority were from the low level staff as shown by $47.1 \%, 42.9 \%$ were from middle management and $10 \%$ were top management. This is an indication that most of the respondent were in a position to give credible information relating to the study.

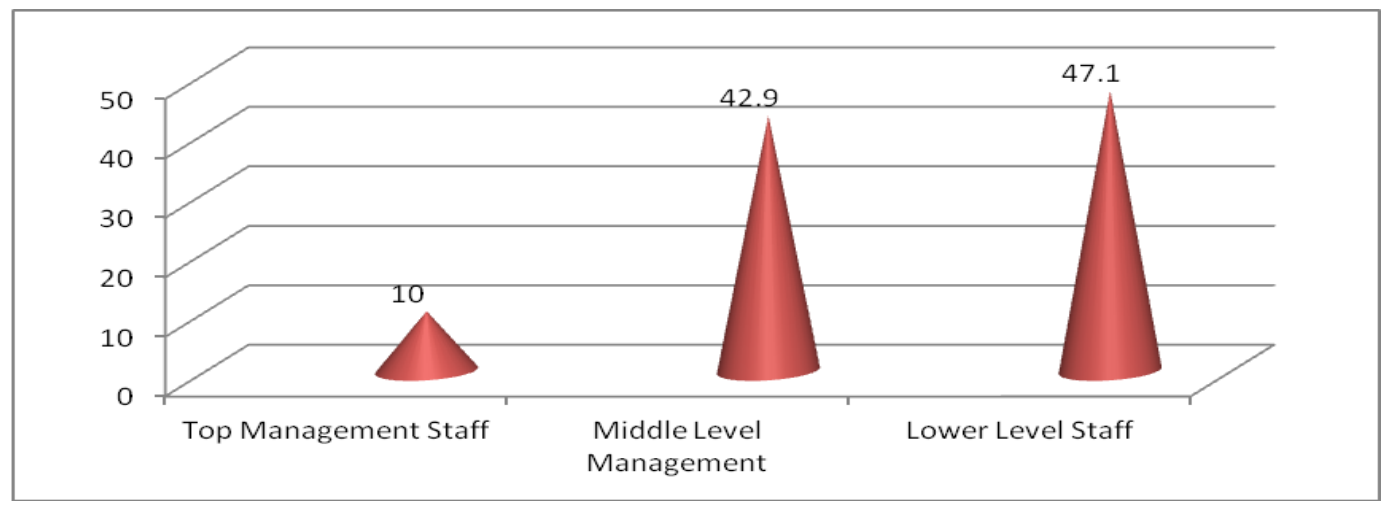

Figure 5: Respondents Level in Organization

\subsection{Descriptive Statistics}

The study sought to establish the extent to which technological factors influence the organizational performance of Kenya Airways Limited. From the findings the study established that majority of the respondents as shown by 45.7 percent indicated great extent, 40 percent indicated very great extent, 8.6 percent indicated moderate extent, and 5.7 percent indicated little extent. This is an indication that technological factors have an influence on the organizational performance of Kenya Airways Limited.

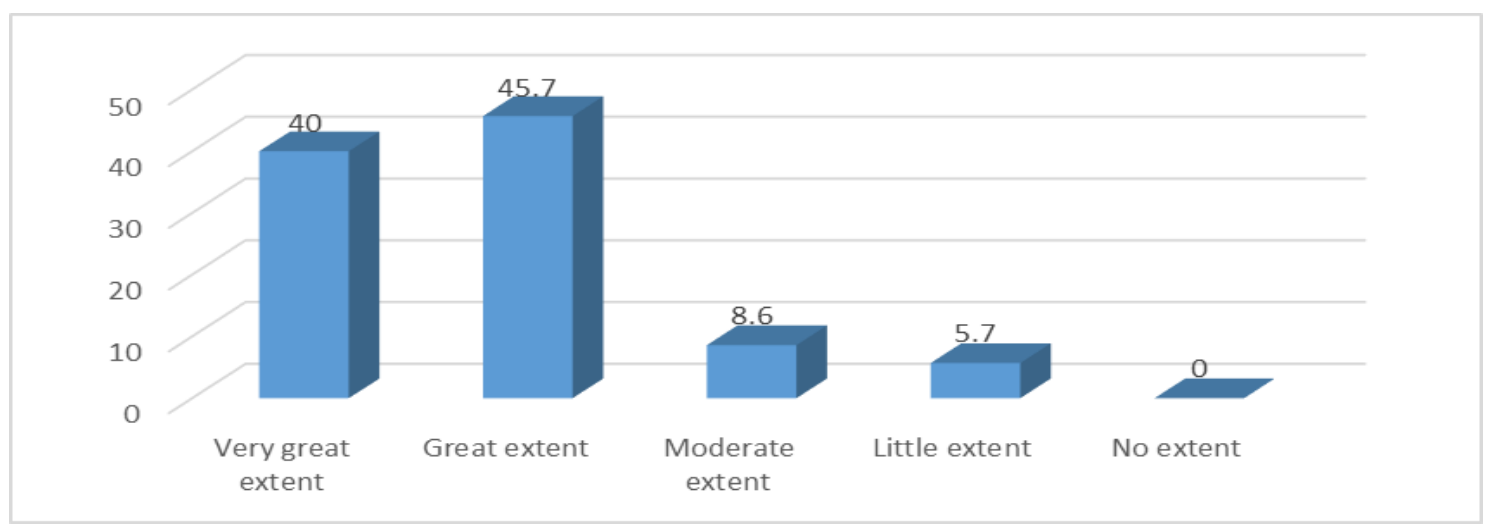

Figure 6: Influence of Technological Factors on Organizational Performance of KQ 
Table 1: Influence of Technological Factors on Organisational Performance

\begin{tabular}{|l|l|l|}
\hline Statement & & \\
\hline Fleet Development affects the organisational performance of Kenya Airways. & 4.06 & 0.93 \\
\hline Passengers are attracted to modern aircrafts. & 4.07 & 1.03 \\
\hline $\begin{array}{l}\text { E-commerce as a sales channel affects the organisational performance of Kenya } \\
\text { Airways. }\end{array}$ & 4.21 & 0.94 \\
\hline Kenya Airways has put mechanisms to drive online sales. & 4.71 & 1.18 \\
\hline $\begin{array}{l}\text { Improved technology on information systems allow managers to take a much } \\
\text { more analytic view of their businesses than before the advent of such systems. }\end{array}$ & 4.30 & 1.02 \\
\hline
\end{tabular}

On the respondent's level of agreement on statements relating to the influence of technological factors on organizational performance of Kenya Airways Limited. The study found that majority of the respondent agreed that Kenya Airways has put mechanisms to drive online sales as shown by a mean of 4.71, improved technology on information systems allow managers to take a much more analytic view of their businesses than before the advent of such systems as shown by a mean of 4.30 , e-commerce as a sales channel influences the organizational performance of Kenya Airways as shown by a mean of 4.21, passengers are attracted to modern aircrafts as shown by a mean of 4.07 , fleet development affects the organizational performance of Kenya Airways as shown by a mean of 4.06. The study established that technological factors influence the organizational performance of Kenya Airways Limited, through change in technologies, new technologies and creation of competitiveness through information technology.

\subsection{Regression Analysis}

The regression analysis for technological factors in relation to organizational performance showed a strong relationship for both efficiency and growth. The results were computed at $95 \%$ confidence level and are summarized and presented in table 2 and 3 below.

Table 2: Technological Factors in Relation to Efficiency of Kenya Airways Ltd

\begin{tabular}{|r|r|r|r|r|}
\hline Model & R & $\begin{array}{c}\text { R } \\
\text { Square }\end{array}$ & Adjusted R Square & Std. Error of the Estimate \\
\hline 1 & $.788^{\text {a }}$ & 0.621 & 0.615 & 0.1543 \\
\hline a. & Predictors: (Constant), Fleet Development, E-commerce \\
\hline b. & Dependent Variable: Efficiency \\
\hline
\end{tabular}

The coefficient of determination was found to be 0.621 . This means $62.1 \%$ of changes in measures of efficiency can be attributed to technological factors. The other variation of $37.9 \%$ is explained by changes in other factors. The coefficient correlation of 0.788 shows that there is a strong relationship between technological factors and efficiency measures of Kenya Airways Ltd.

Table 3: Technological Factors in Relation to Growth of Kenya Airways Ltd

\begin{tabular}{|r|r|r|r|r|}
\hline Model & R & $\begin{array}{c}\text { R } \\
\text { Square }\end{array}$ & Adjusted R Square & Std. Error of the Estimate \\
\hline 1 & $.828^{\mathrm{a}}$ & 0.686 & 0.791 & 0.388 \\
\hline a. & \multicolumn{5}{|c|}{ Predictors: (Constant), Fleet Development, E-commerce } \\
\hline b. & Dependent Variable: Growth
\end{tabular}

The coefficient of determination was found to be 0.686 . This means $68.6 \%$ of changes in growth can be attributed to technological factors. The other variation of $31.4 \%$ is explained by changes in other factors.

The coefficient correlation of 0.828 shows that there is a strong relationship between technological factors and growth of Kenya Airways Ltd.

\subsection{Findings}

The objective of the study was to establish the influence of technological factors on the organizational performance of Kenya Airways Limited. The study revealed that technological factors influence organizational performance of Kenya Airways Limited. The study also established that Kenya Airways has put mechanisms to

DOI: $10.9790 / 0837-2205050107 \quad$ www.iosrjournals.org $\quad 5 \mid$ Page


drive online sales, improved technology on information systems, e-commerce as a sales channel affects the organizational performance of Kenya Airways, passengers are attracted to modern aircrafts and fleet development affects the organizational performance of Kenya Airways. The study also established other technological factors that influence organizational performance which is the advent of new systems which help in benchmarking thus improving efficiency and growth. Paperless ticketing and customer friendly internet interface allows for real time online booking, ticketing and checking in which improves the customer journey and improves overall performance of airlines.

\section{CONCLUSION}

The study established technological factors influence the organizational performance of Kenya Airways Limited. This was in line with the findings of Kessides (2004) found that technological advancement has been the driving factor for improving airlines' operational efficiency. Airlines have been able to reduce costs and improve operations by using advanced aircraft engine technology, IT solutions, and mobile technology. Technology has created better connectivity and enhanced passengers' travel experience. Kenya Airways recent fleet renewal program will mean reduced fuel consumption which directly improves the airlines performance. Ecommerce as sales channel has shown major improvements as result of various initiatives that have been put in place to drive online sales e.g PayPal. Kenya Airways has also partnered with Safaricom Ltd to enable its passengers to redeem bonga points for air tickets.

\section{RECOMMENDATION}

The study recommends that there is need for the management of Kenya Airways to adopt modern technologies in the airline industry. This will help in making them competitive and thus improving their performance as the study revealed that technological factors have a strong influence organizational performance of Kenya Airways Limited.

\section{ACKNOWLEDGEMENTS}

I would like to acknowledge the following persons whose contributions facilitated the completion of this project. First, I thank the Almighty God for the gift of life and for giving me the skills, knowledge and energy to be able to complete this paper. Secondly, special thanks go to my supervisor, Dr Susan Wekesa, for providing unlimited, invaluable and active guidance throughout the study. Her immense command and knowledge of the subject matter enabled me to shape this research project. Thirdly, I am blessed with wonderful family and friends who encouraged me and supported my work. My husband, Charles Kikuvi, who has strongly encouraged me and always supported my choices. I also acknowledge my children Bradley, Victoria and Elizabeth for their patience, prayers, and support during my study period.

\section{REFERENCES}

[1]. Ansoff, H.I., \& McDonnell, E.J. (2010). Implanting strategic management. New York, NY: PrenticeHall.

[2]. Davis, G.F., \& Powell, W.W. (2012). Organization-environment relations. In: Dunnette, M.D., \& Hough, L.M. (Eds.). Handbook of industrial organizational psychology, $2^{\text {nd }}$ Ed. Palo Alto, CA: Consulting Psychologists Press.

[3]. Friendman, W.W. (2010). Organization-environment relations. In: Dunnette, M.D., \& Hough, L.M. (Eds.). Handbook of industrial organizational psychology, $2^{\text {nd }}$ Ed., Palo Alto, CA: Consulting Psychologists Press.

[4]. Hassan, M. K., and Bashir A. H. M. (2003). Determinates of Islamic banking profitability. Paper presented at the Economic Research Forum (ERF) 10th Annual Conference, Marrakesh, Morrocco, 16-18 December.

[5]. Hough, J.R., \& White, M.A. (2003). Environmental dynamism and strategic decision making rationality: an examination at the decision level. Strategic Management Journal, 24(3), 481-489.

[6]. Illo, A.D., (2012). The effect of Macroeconomic Factors on Financial Performance of Commercial Banks in Kenya. Unpublished MSC project, University of Nairobi, 2012.

[7]. Johnson, G and Scholes, K (2007). Exploring Corporate Strategy, $7^{\text {th }}$ edition. Harlow, US: Financial Times Prentice Hall.

[8]. Kessides, I. (2004). Reforming Infrastructure: Privatization, Regulation, and Competition. Washington, USA: Oxford University Press. Retrieved: $20^{\text {th }}$ August 2015.

[9]. Kotler, P. \& Armstrong, G. (2000). Principles of Marketing, Ninth Edition, Prentice-Hall, Inc., Upper Saddle River, New Jersey 07458. 
[10]. KQ 2013. Annual Report 2014, September. Retrieved from https://www.kenyaairways.com/global/About Kenya Airways/Investor Information/Investor_News/

[11]. KQ 2014. Annual Report 2015, September. Retrieved from https://www.kenyaairways.com/global/About Kenya Airways/Investor Information/Investor_News/

[12]. Lynch, R. (2003). Corporate strategy. $3^{\text {rd }}$ Ed. New York: Prentice-Hall.

[13]. Mitchell, J.R., Shepherd, D.A., \& Sharfman, M.P. (2011). Erratic strategic decisions: when and why managers are inconsistent in strategic decision making. Strategic Management Journal, 32, 683-704.

[14]. Mugenda, O. \& Mugenda, A. (2008). Research Methods; Quantitative and Qualitative Approaches. Nairobi: Acts Press.

[15]. Rao, S.R. (2008). Organizational environment. Citeman Network. Retrieved on $16^{\text {th }}$ August 2015. html.www.citeman.com/3952 organizational environment.

[16]. Robert B. Carton, Charles W. Hofer, (2006). Measuring Organizational Performance: Metrics for Entrepreneurship and Strategic Management Research. Edward Elgar Publishing Limited. 